(Wilno, IT)

\title{
LIST PAPIEŻA HORMIZDASA DO CESARZA ANASTAZEGO I
}

\author{
„Non genus, non gens, $[\ldots]$ \\ sed mens nobilitat nobilitata virum"1
}

Na Jubileusz Księdza Profesora Stanisława Longosza należałoby propter meliorem ordinem ${ }^{2}$ pójść dalej tym tropem i napisać garść słów in forma amplissima ${ }^{3}$ tylko w języku łacińskim. Tego wymaga i rzymska postać Jubilata, i antyczne dzieje Kościoła, których jest On znamienitym badaczem. Ze względu jednak na to, że niewielu dziś zna ów język, pozwalam sobie zadedykować przekład listu biskupa Rzymu Hormizdasa (514-523) na ojczystą naszą mowę, licząc ze strony czytelnika na uważną jego lekturę. Ex ratione duplici ${ }^{4}$ umieszczam w Księdze Jubileuszowej owo tłumaczenie. Racja pierwsza jest ta, że za zaszczyt największy poczytuję sobie przynależność do grona uczniów-przyjaciół dostojnego Jubilata i zależy mi na tym, by Historia przyznała, iż rzeczą słuszną jest, że Ks. Profesor laudabatur ab illo, qui erat [...] rotundo $o r e^{5}$. Wiele by można pisać, lecz jedną rzecz chcę podkreślić w Osobie Jubilata - Jego szlachetny umysł. Na niego składa się męstwo i mądrość - owe dary Ducha Dokonawcy, które pozwalają człowiekowi być sobą w każdym czasie podług łacińskiej maksymy:

„Qui sapis, ad vitam sapias; gere conscia recti:

Pectora nec strepitu commoveare levi” ${ }^{\circ}$.

Ci, którzy znają Ks. Profesora wiedzą, że jest on żywym uosobieniem owej maksymy. A racja druga dla zadedykowania owego przekładu papieskiego

${ }^{1}$ Jan Chryzostom Pasek, Pamiętniki (Rok 1683. Apostrophe), oprac. R. Pollak, Warszawa 1989, 251, tłum.: „Nie pochodzenie, nie ród, lecz szlachetny umysł uszlachetnia męża”.

2 Tamże (Rok 1672), s. 209, tłum.: „Dla lepszego porządku”.

3 Tamże (Rok 1672), s. 209, thum.: „Stylem bardzo ozdobnym”.

4 Tamże (Rok 1660), s. 57, tłum.: „Z dwojakiej przyczyny”.

5 Tamże (Rok 1660), s. 50, tłum.: „Chwalony był przez tego, który był [...] wymowny”.

${ }^{6}$ Tamże (Rok 1661), s. 107, tłum.: „Jeżeliś mądry, okazuj mądrość swą w życiu: zachowaj czyste sumienie i nie trwóż się za lada szelestem". 
listu jest taka, że Jubilat - który słusznie jest Prałatem Jego Świątobliwości papieża Benedykta XVI, sukcesora Hormizdasa na Rzymskiej Stolicy - jak mało kto rozumie realizowanie się prymatu św. Piotra, także w starożytności. A list papieski, niżej zaprezentowany w wydaniu A. Thiela jako 27, jest tego dobrym przykładem. Napisał go papież 3 kwietnia 517 r. po tym, jak cesarz Anastazy (491-518) usiłował skłócić papieża z rzymskim senatem w sprawie jednomyślności w potępieniu patriarchy Konstantynopola Akacjusza, jako warunku przywrócenia jedności w Kościele. Próba ta nie powiodła się władcy Bizancjum, a papież nadal okazując dobrą wolę kontynuował rozmowy zjednoczeniowe. W tym celu wiosną 517 r. udali się do stolicy Bizancjum dwaj wysłannicy papiescy, biskup Ennodiusz z Pawii i biskup Misseny Peregrynus. Wieźli oni ze sobą bogatą korespondencję, nie tylko do cesarza, ale i do biskupów Wschodu, co świadczyło o zamiarach prowadzenia rozmów zakrojonych na szeroką skalę. W oficjalnym liście skierowanym do cesarza, zachęca papież władcę do konsekwencji w pomyślnym zakończeniu rozłamu w Kościele, skoro sam rozpoczął działania idące w tym kierunku. Oczywiście postulat potępienia Akacjusza nie uległ zmianie, jak również i to, że papież delikatnie przypomina potrzebę liczenia się w kwestii wiary z Rzymem.

Myślę, że i Ks. Profesor i jego przyjaciele, jako generosae aquilae pulli ${ }^{7}$, odczytają przetłumaczone słowa listu papieża podług jego najgłębszego sensu, czyli realizowania przez Kościół Chrystusowego życzenia: ut unum sint! (J 17, 21). To życzenie Zbawiciela towarzyszyło też mnie w przekładaniu tego listu, by słowo papieża Hormizdasa, następcy św. Piotra na Rzymskiej Stolicy, okazało się wyrazicielem tego życzenia w sercu moim, przyjaciół Jubilata i Jego samego, podług słów: Iste est interpres meorum et vestrorum desideriorum ${ }^{8}$.

\section{WYDANIA}

A. Thiel, Epistolae Romanorum Pontificum genuinae a S. Hilario usque ad Pelagium II, Brunsbergae 1868, 796-800.

O. Günther, CSEL 35/2, Wien 1898, 540-544

\section{BIBLIOGRAFIA}

J.E. Anastasiou, Relations of Popes and Patriarchs of Constantinopole in Frame of Imperial Policy from the Time of the Acacian Schism to the Death of Justynian, w: I patriarcati orientali nel primo millenio, Roma 1968, 55-69; P. Ba-

\footnotetext{
7 Tamże (Rok 1660), s. 51, tłum.: „Szlachetnego orła pisklęta”.

8 Tamże (Rok 1659), s. 251, tłum.: „Oto jest tłumacz moich i waszych życzeń”.
} 
tiffol, Cathedra Petri. Etudes histoire ancienne de l'Église, Paris 1938; tenże, La Siège de Rome et l'Orient dans l'histoire ancienne de l'Église, „La Revue Apologétique" 40 (1928) 288-302; K. Baus - H. Beck - E. Ewig - H.J. Vogt, Die Kirche von Ost und West von Chalkedon bis zum Frühmittelalter, Freiburg 1975; S. Bralewski, Obraz papiestwa w historiografii kościelnej wczesnego Bizancjum, Łódź 2006; E.W. Brooks, The Eastern Provinces from Arcadius to Anastasius, w: The Cambridge Medieval History, I, Cambridge 1911, 457486; C. Capizzi, L'imperatore Anastasio (491-518), Roma 1969; tenże, Sul fallimento di un negoziato di pace ecclesiastica fra il papa Ormisda e l'imperatore Anastasio I, „Critica Storica” 17 (1980) 23-54; E. Caspar, Geschichte des Papsttums von den Anfängen bis zur Höhe der Welterrschaft, I-II, Tübingen 19301933; J. Chapin, Hormisdas, w: New Catholic Encyclopedia, VII, New York 1967, 248; P. Charanis, Church and State in the Later Roman Empire. The Religions Policy of Anastasius the First (491-518), Madison 1939, Thessalonike $1974^{2}$; P. Conte, Chiesa e primato nelle lettere dei papi del secolo VI-VII, Milano 1971, 407-423; L. Duchesne, L'Église au VI siécle, Paris 1925; A. Fliche - V. Martin, Histoire de l'Église, IV, Paris 1945; O. Günther, Beiträge zur Chronologie der Briefe des Papstes Hormisda, Wien 1892; W. Haacke, Die Glaubensformel des Papstes Hormisdas im Acacianischen Schisma, Roma 1939; S. Koczwara, Wokót sprawy Akacjusza, Lublin 2000; Magistero, cura pastorale e impegno ecumenico. Atti del convegno su papa Ormisda (514-523), Frosinone 1993; E. Schwartz, Publizistische Sammlungen zum Acacianischen Schisma, München 1934; A.A. Vasiliev, A History of the Byzantine Empire 322-1453, Madison 1952; J. Verger, Naissance et premier essor de l'Occident chretien ( $V^{e}$ $\left.X I I I^{e}\right)$, Paris 1975; J. Wojda, Les trois premiers voyages des papes de Rome à Constantinople (484-555), Siedlce 2006.

\section{PRZEKEAD*}

Hormizdas cesarzowi Anastazemu przez biskupów Ennodiusza i Peregryna

Wnet po przyjeździe waszych legatów udzieliłem odpowiedzi na wasz list i zalecenia, choć nie tak kompletnie, jak wymagała tego ważność rzeczy, rozwiązując tylko tymczasowo niektóre sprawy, a należało dostatecznie załatwić wszystko. Jednak, czyż mógłbym przez ponawiane prośby do Waszej Łaskawości nie dość starać się o dobro wiary? Niech poczuwają się do odpowiedzialności za niedbalstwo ci, na których barkach leży obowiązek dbania o ziemskie sprawy. Nie wypełnia dzieła ewangelicznego ten, który uważa, iż bez większej

* Tłumaczenia dokonano z łacińskiego tekstu krytycznego w wydaniu O. Günthera, CSEL $35 / 2,540-544$. 
winy może sobie darować jej głoszenie, bo gorliwemu pasterzowi należy pełnić straż i mieć ustawicznie przepasane lędźwia, bo, jak wiadomo, nie powinno się znudzić udzielanie upomnień przynoszących zbawienne skutki. Któż więc może powiedzieć, że nużę Waszą Łaskawość powtarzaniem moich postulatów, jeśli przez to, co ja czynię z mego obowiązku, równocześnie przychodzi korzyść dla waszej jurysdykcji w dziedzinie wiary?

Ta troska, która mnie dręczy, was odciąża. Na mnie ona spoczywa, dla was jest pożytkiem. Z działań nas obydwu ma być owoc, bo jak winą jest nie mówić i nie czynić tego, co się Panu Bogu podoba, tak też i nagroda przypada i temu, kto głosi sprawy Boże i temu, kto nie odrzucił tego, co usłyszał.

Dała Wasza Łaskawość w cesarskim liście rękojmię jedności i związała się jakby zastawem swej dobrej woli, lecz to nie wystarczy: należy zapewnić stałość zaczętym działaniom. Niech rzucone już fundamenty uzyskają pełną świetność. Nie powinni opuszczać rąk walczący za Kościół Boży. Tylekroć bowiem ponosił klęskę wróg Izraela, ilekroć Mojżesz nie opuszczał ramion (Wj 17, 11). Podjęte dzieło chwali wynik, a zakończenie świadczy o tym, jakie były początki. Nie wystarczy zacząć ratować, ponieważ tylko stałość w wierze zapewni zbawienie.

Dziękujemy Bogu, że gorliwość Waszej Pobożności daje wyraz tego, iż chce nienawidzić bezbożników Nestoriusza i Eutychesa oraz twierdzi, że walczy z bluźnierczymi dogmatami. Ten daje dowód, że prawdziwie nienawidzi błędów, kto skazuje błądzących; nie pozostawia sobie możliwości zboczenia z prawej drogi, kto nie pobłaża przestępcy. Pierwszym stopniem prawości wiary jest odwracać się od wszystkiego, co jest grzechem, ale rzeczą prawowierności i katolickiej dyscypliny jest, Panie mój i Synu, byście mieli w nienawiści także i naśladowców oraz zwolenników wyżej wymienionych, skoro owych heretyków uznaliście za godnych potępienia. Potępić trzeba nie tylko owe dobrze znane nam imiona, lecz także tych, którzy idą za potępionymi, błędy należy wykorzenić. Fałszywie postępuje ten, który twierdzi, że odwraca się od wielu, jeżeli zrobił wyjątek, choćby dla jednego. Bo przecież nie jest decydujące to, jaka jest liczba błądzących, lecz na uwadze mieć trzeba przede wszystkim samą istotę herezji.

Przeto więc niech nie sądzi, Wasza Łaskawość, lekkomyślnie, że może sobie darować osobę Akacjusza. Czyż to nie jest ów Akacjusz, który dołącza się i zanurzony jest w bagnie błędów Piotra, Dioskura i Eutychesa, skażonych co do nauki i co do jedności? Czyż razem z tymi, z którymi wszedł w łączność, nie powinien ponieść kary? A więc kto zdecydowanie potępia bezbożność tamtych, koniecznie winien dołączyć do ich grona i Akacjusza oraz wszystkich z nim związanych. Od niego zakorzenił się w Kościołach Wschodnich ferment godnego potępienia błędu. Z niego zrodziła się perfidia Kościoła Aleksandryjskiego i dotąd aż trwa jego pycha. Bo, jak piszecie, nie stosuje się on do zbawiennych zaleceń tego, którego władzy podlega, a podtrzymując błędy, nie respektuje jego poleceń uważając, że sam może w tych sprawach decydować. 
Należy więc tego rodzaju ludzi dotknąć większym niż dotąd potępieniem, albowiem oni też nie stosują się do tego - mimo iż powinni - czego nauczają, i gardzą upomnieniem cesarza, a przecież winni nie tylko respektować jego władzę, lecz także baczyć na dobro zbawienia, o które nie dbają. Tychże to pozbawionych rozumu ośmiela się protegować Akacjusz, utrzymując z nimi wspólnotę. Dlatego uważać go należy za przywódcę, gdyż w szczególny sposób zgrzeszył złym przykładem. Nic tak bardzo nie sprzyja rozszerzaniu się błędów, jak ich naśladowanie : kiedy wierni wiedzą, że nie jest to zakazane, podobnie postępują. Tak jest bowiem ułomna i słaba ludzka natura. Nie wykorzeni się przez prześladowanie niegodziwych myśli, bowiem złe nasienie nie traci przez to swej witalnej mocy. Szeroko otwiera dostęp dla grzeszników ten, kto godzi się na przewrotność.

Oby więc, Najłaskawszy Cesarzu, wschodnie Kościoły unikały łączności z Akacjuszem! Przez niewielu błąd ten rozlał szkodliwą truciznę. Zapewne, nawet mury Aleksandrii wówczas by runęły, gdyby poznawszy ową bezbożność i widząc potępienie naśladowców herezji, nie zaniechały sprzeciwu. Gdy sprzyja się błędom i zaniedbuje naprawy niegodziwości uprawianiem niepotrzebnej tolerancji, to przez zapewnienie bezkarności zwolennikom powiększa się jeszcze oddziaływanie nauki heretyków. Wy więc, Cesarzu, zarządźcie stosowanie się do tego, co Bogu się podoba i zadeklarujcie, jakie jest wasze zdanie o cudzych błędach, a pomyślcie przy tym, czy wobec Boga wystarczy jedynie wytykać to, co jest błędem, jeżeli ma się możność je naprawić. Kuracji przeto nie wolno odkładać. Przyłóżcie lecznicze ręce do uleczenia głębokich ran! Przed Akacjuszem sama tylko Aleksandria cuchnęła swoją szpetnością. Zauważcie, Najłaskawszy Cesarzu, jak kolejne terytoria zostały zarażone, gdy zaniedbało się wysiłków poprawy stanu rzeczy! Jak długo będziesz tolerował, Panie i Synu, to, że Kościół Boży płacze nad podziałem swoich członków? Niech twoje dobre czyny uprzedzą to, do czego wzdychają zanoszone do Boga modlitwy! Podejmij troskę o wiarę i wznosząc chorągiew zbawienia, powstań, jak drugi Ezechiasz, by oddalić błędy od Izraela. Godzi się tobie blaskiem nowych czynów dorównać tytułom chwały przodków. On zniszczył wyżyny, ty upokorz pychę wynoszących się niegodziwości. On skruszył bałwany, ty skrusz oporne serca niewiernych. On powtórzył historię miedzianego węża, ty zniwecz teraźniejsze trucizny. Oddaj Bogu to, co sprawiedliwe, jak on to uczynił i oczekuj nagrody, na którą tamten zasłużył. Wierny jest bowiem Pan i odda każdemu według jego uczynków. Wiadomo jest, czego oczekują wierni, a czego boją się bezbożni; ci pragną cieszyć się z aniołami z tego, co otrzymają, tamci zaś się trwożą, by porzuceni przez tych, których uwiedli, nie podpadli oczekujących ich karom: w zawieszeniu pozostają strwożone serca wszystkich.

Z najdalszych krańców Galii dotarło do nas poselstwo z pytaniem, bo już rozeszła się szeroko wieść o tym, co wasza troskliwość uczyniła dla przywrócenia jedności? Dla Waszej Łaskawości nie jest to trudne, bo umie Bóg wspo- 
magać prace swoich wiernych, a wiadomo, jak do swoich władców zwracają się serca poddanych. Niech powtórzy się w nowym wydaniu przykład niedawno zmarłego świętej pamięci cesarza Marcjana. Co uczynił wówczas tłum i naród? Nie trzeba przypominać tego, co znamy. Przez zbłąkanych wzmocniła się owa perfidia, a przez sprawiedliwych nauka Pana. W sprawach religijnych naśladuj to, czego dokonałeś w rządach państwem.

Naszymi łzami i prośbami popieramy nasze pełne czci pozdrowienie dołączone do poselstwa naszych braci i współbiskupów Ennodiusza i Peregryna występujących w naszym zastępstwie. A przeto nakładając specjalnemu posłańcowi sprawy drugiego poselstwa, oczekujemy, by przyniósł nam początki dobrej nadziei. Tak więc przy pomocy Bożej, postarajcie się, by przyniósł nam od dawna oczekiwany i upragniony skutek.

Napisany: w III Nony kwietnia, za najjaśniejszego konsula Agapita.

Z języka łacińskiego przełożył, wstępem i komentarzem opatrzył Ks. Stanisław Koczwara

EPISTOLA HORMISDAE PAPAE AD ANASTASIUM I IMPERATOREM (Argumentum)

Hac in brevi dissertatiuncula post introductionem cum annexa bibliographia proponitur prima in linguam Polonorum translatio Epistolae Hormisdae papae ad Anastasium I imperatorem. 